症例

広範囲に進展したアポクリン非浸潤性乳管癌の 1 切除例

国立病院機構小倉病院外科・臨床研究部, 同 病理部*, 北九州市立医療センター外科**, 産業医科大学第 2 病理学教室***

沖野秀宣島田和生渡辺次郎*

光山昌 珠** 笹栗毅 和***武田成彰

広範囲に進展したアポクリン非浸潤性乳管癌（apocrine ductal carcinoma in situ, 以下 ADCIS)の 1 例を経験した．症例は44歳の女性で右乳房の大きなしこりを主訴に来 院した. マンモグラフィでは多形性, 微細線状石灰化がびまん性にみられ, 針生検で DCIS と診断された. 術中のセンチネルリンパ節生検で転移を認めず, 単純乳房切除術を 施行した，病理組織診断ではほとんどの細胞がアポクリン細胞の特徴を呈し，乳管外に 浸潤する病変を認めず Comedo 型の ADCIS と診断された。免疫組織学的には GCDFP15, Ki-67, HER-2が陽性, エストロゲン, プロゲステロン, アンドロゲンレセプターは 全て陰性であった．文献上ADCIS はホルモンレセプター発現を含む生物学的性質が通 常のDCIS とは異なることが報告されており，組織学的分類上の位置付けを明確にする 必要があると考えられた。

臬引用語：アポクリン化生，非浸潤性乳管癌，ホルモンレセプター

\section{緒 言}

乳房の上皮性疾患におけるアポクリン化生は衰胞性 疾患, 過形成, 腺腫, 腺癌などにしばしばみられるが" 非浸潤性乳管癌 (ductal carcinoma in situ, 以下 DCIS) 症例が増加するに従い, この中にも多くの細胞 がアポクリン細胞の特徵を呈し,いわゆるアポクリン DCIS（以下 ADCIS）と定義可能な症例が増えつつあ る.

今回, 広範囲に進展したADCIS の 1 例を経験した ので, 特に通常の DCIS とは異なるホルモンレセプタ 一発現を中心とした文献的考察を加え報告する。

\section{症例}

患者：44歳, 女性.

主訴：右乳房のしこり。

現病歴：平成15年 6 月右乳房の広範囲におよぶしこ りを触知したため近医を受診, 当科へ紹介となった。

既往歴：24歳時より統合失調症。

家族歴, 生活歴：特記事項なし。

2005年11月 4 日受付 2005年12月21日採用 〈所属施設住所〉

テ 802-8533 北九州市小倉南区春ヶ丘10-1
入院時現症: 右乳房 $\mathrm{A}, \mathrm{C}, \mathrm{D}$ 領域に長径 $14 \mathrm{~cm}$, 弾 性軟で境界不明瞭なしこりを認めた。皮阊と乳頭には 異常を認めず，腋穸リンパ節も触知しなかった。

入院時検查所見：CEA, CA15-3, NCC-ST-439はい ずれも正常であった.

マンモグラフィ：明らかな腫瘍陰影は認めなかった が, 右乳房に散在する局所性非対称陰影と共にびまん 性の多形性, 微細線状石灰化を認め, カテコリー 5 と 診断した（図 1 ).

乳腺超音波：微細高エコースポットを伴うびまん性 の不規則な低エコー領域（図 $2 \mathrm{~A}$ ) や, 乳管の拡張が みられた（図 $2 \mathrm{~B}$ ).

針生検：エコーガイド下に得られた組織は悪性て， 浸潤性病変はみられず DCIS と診断された。

手術所見：広範囲に伸展したDCIS, TisN0M0, Stage 0の診断で手術を施行した.インジゴルミン


転移陰性であったため, 単純乳房切除術を施行した。

切除標本：乳腺組織はびまん性に硬く触れ, 割面に は大小の石灰化が無数に認められた（図 3 ).

病理所見：90\%以上の癌細胞は好酸性の細胞質と明 瞭な核小体を有する大きな円形の核を有しており，乳 


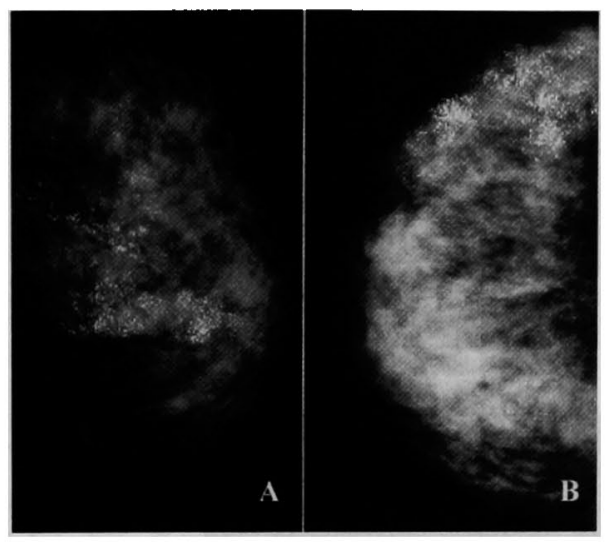

図 1 マンモグラフィ：右乳房に散在する局所 性非対称陰影と共に,びまん性の微細線状石灰 化がみられた。明らかな腫瘍性病変は認めなか った (A MLO像, B CC 像).
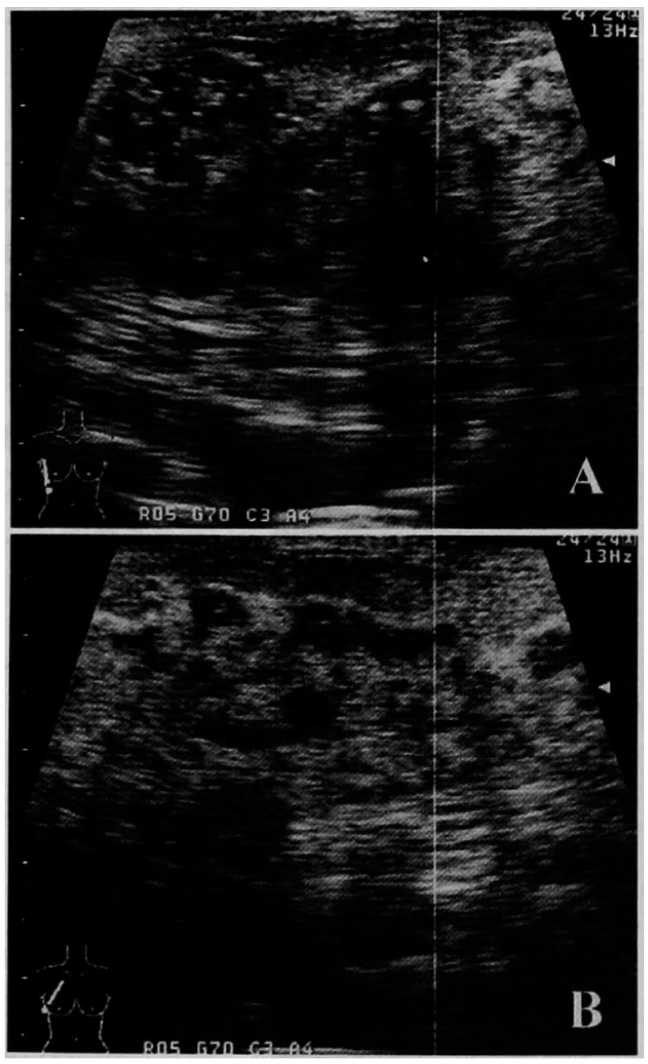

図 2 乳腺超音波：A）微細高エコースポットを伴 うびまん性の不規則な低エコー領域と，B）不規則 な乳管の拡張の多発を認めた。



図 3 切除標本：乳腺組織はびまん性に硬く触れ，大小 の石灰化が無数に認められた。

管外に浸潤する病変をいずれの箇所にも認めず, Comedo 型の ADCIS と診断した（図 4).

免疫組織学的検查 : Gross cystic disease fluid protein(以下 GCDFP-15)，Ki-67, HER-2は陽性, エス トロゲンレセプター(以下 ER), プロゲステロンレセ プター（以下 $\mathrm{PgR}$ ), アンドロゲンレセプター（以下 AR）はいずれも陰性であった（図 5 ).

経過：術後 2 年経過した現在, 再発の兆候はみられ ず経過は良好である。

考 察

乳腺のアポクリン癌は日本乳癌学会の癌取扱い規約 上,アポクリン化生を伴う浸潤癌の特殊型として定義 されるが2)，アポクリン化生を伴う非浸潤癌である ADCIS はこの範詈には分類されない.組織学的評価基 準がいくつか提唱されているものの ${ }^{344)}$, ADCIS の明 確な診断基準は確立されておらず，したがってその臨 床学的および生物学的特徵は不明な点が多かった。し かし近年, 症例の報告と集積が徐々に進み, その病態 が明らかになりつつある。

Tavassoli ら5は37例の ADCIS を検討し, ADCIS は通常の DCIS と比較して臨床学的に大きな相違はな く, 腋㸗リンパ節転移や再発を認めた症例はないと報

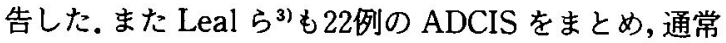
の DCIS の臨床学的特徵は類似し予後は極めて良好と 報告している.したがって ADCIS に対する診断, 治療 方針は通常の DCIS の治療と同様とみなしてよいと考 えられる。

しかし一方では, ADCIS は通常の DCIS とは異なる ホルモンレセプターの発現を含めた生物学的特徵を有 するとされている. GCDFP-15と呼ばれる15kDa の糖 




図 4 病理所見：癌細胞は好酸性の細胞質と明瞭な核小体を有する大きな円形の 核を有しており，乳管外に浸潤する病変をいずれの箇所にも認めず, Comedo 型 (矢印：壊死巣) の ADCIS と診断した（HE 染色, A × $100, B \times 400, C \times$ $1,000)$.

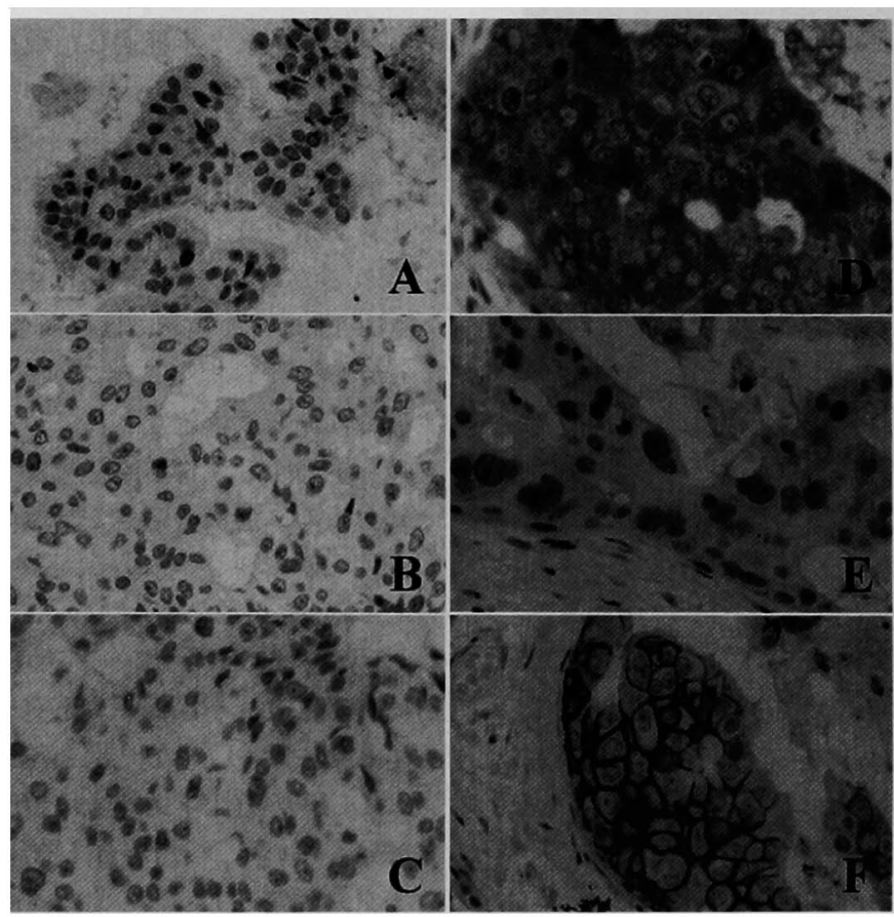

图 5 免疫組織学的所見：A）ER 陰性，B） PgR 陰性，C）AR陰性, D) GCDFP-15陽性，E）Ki-67陽性，F） HER-2 (3+) $(\times 400)$. 
表 1 DCIS と ADCIS のホルモンレセプター発現の比較

\begin{tabular}{lcccc}
\hline & & 高分化型 & 中分化型 & 低分化型 \\
\hline \multirow{3}{*}{ DCIS $^{3 / 8)}$} & AR & $23 \sim 95 \%$ & $53 \sim 73 \%$ & $26 \sim 76 \%$ \\
& ER & $100 \%$ & $53 \sim 91 \%$ & $8 \sim 32 \%$ \\
& PgR & $92 \sim 95 \%$ & $42 \sim 55 \%$ & $0 \sim 32 \%$ \\
\hline \multirow{3}{*}{ ADCIS $^{10)}$} & AR & $100 \%$ & $100 \%$ & $93 \%$ \\
& ER & $0 \%$ & $10 \%$ & $6.7 \%$ \\
& PgR & $0 \%$ & $10 \%$ & $0 \%$ \\
\hline
\end{tabular}

タンパクはアポクリン化生を示すマーカーとして用い られているが文,このマーカーは80\%の ADCIS で陽性 を示すとされており7，本症例でも陽性であった。 GCDFP-15は通常の DCIS の $40 \%$ に陽性を示すとさ れ》,これはアポクリン細胞の特徵を持たない通常の DCIS も，機能的にアポクリン活性を有する可能性が あることを示唆すると考えられる。

$\mathrm{AR}$ は乳腺上皮のアポクリン細胞への分化の指標と しても知られており，今回のわれわれの症例では AR 㹥性であったが，60\%の浸潤癌，82\%の通常の DCIS, 97\%の ADCISにその発現がみられる318). Matsuo ら”はアポクリン癌を，1) intraductal spreading type, 2 ) adenosis-associated type, 3 ) infiltrating typeの 3 つに分類したが, ADCIS はそのうち(1)の分 類の一部に属するものと考えられる。また Leal ら ${ }^{3}$ は アポクリン癌細胞の核異型度と壊死の程度により ADCIS を, 1) low grade, 2 ) intermediate grade, 3 ) high grade $の 3 つ に$ 細分化する概念を提唱してい る.この概念に従い組織分化型によりホルモンレセプ ターの発現を整理すると, AR は ER および PgR とと もに通常の DCIS に高頻度に発現するが，その免疫組 織学的陽性率は細胞の分化度が低くなるに従い低下す る(表 1$)^{338)}$.これに対し ADCIS は分化の程度に関わ らず常に高い ARの発現と常に低い $\mathrm{ER}$ 抢よび PgR の発現を示すことが報告されている(表 1) ${ }^{10)}$ 。この結 果は，分化度によるホルモンレセプターの不均一性を 示す通常の DCIS と顕著な対照をなし, ADCIS の生物 学的性質として論議されている101.このホルモンレセ プターの特徴を説明する機序として，アポクリン細胞 への分化が引き金となった ARのアップレギュレー ションが $\mathrm{ER}$ と PgRのダウンレギュレーションを起 こすというレセプター相互のリンクが報告されている が11), 未だ不明の点が多い.

ホルモンレセプター以外のマーカーでは, ADCIS で も本症例のように HER-2と Ki-67の発現が高い症例
はより悪性度が高いとされ3)，腫瘍の大きさからみて も, 今後とも十分な経過観察が必要と思われる。

通常の DCIS と臨床的には類似するものの, 明らか に異なった生物学的特徵を有する ADCIS の報告例は 近年, 徐々に增加しており, ADCIS の病理学的位置付 けを明確にする必要があると考えられた。

\section{文献}

1) Eusebi V, Damiani S, Losi $L$, et al: Apocrine differentiation in breast epithelium. Adv Anat Pathol 4 : 139-155, 1997

2) 日本乳癌学会編：乳癌取扱い規約. 第14版, 金原 出版, 東京, 2000

3) Leal $C$, Henrique $R$, Monteiro $P$, et al : Apocrine ductal carcinoma in situ of the breast : histologic classification and expression of biologic markers. Hum Pathol 32 : 487-493, 2001

4) O'Malley FP, Page DL, Nelson EH, et al: Ductal carcinoma in situ of the breast with apocrine cytology: definition of a borderline category. Hum Pathol 25 : 163-168, 1994

5) Tavassoli FA, Norris $\mathrm{HJ}$ : Intraductal apocrine carcinoma: a clinicopathologic study of 37 cases. Mod Pathol 7: 813-818, 1994

6) LeDoussal V, Zangerle PE, Collette J, et al: Immunohistochemistry of a component protein of the breast cystic disease fluid protein of mol. Wt. 15,000. Eur J Cancer Clin Oncol 21 : 715725, 1985

7) Selim AA, El-Ayat G, Wells C: Immunohistochemical localization of gross cystic disease fluid protein-15, -24 and -44 in ductal carcinoma in situ of the breast : relationship to the degree of differentiation. Histopatol 39 : 198202, 2001

8) Moinfar F, Okcu M, Tsybrovsky $O$, et al : 
Androgen receptors frequently are expressed in breast carcinomas : potential relevance to new therapeutic strategies. Cancer 98:703-710, 2003

9) Matsuo $K$, Fukutomi $T$, Hasegawa $T$, et al : Histological and immunohistochemical analy. sis of apocrine breast carcinoma. Breast Cancer $9: 43-49,2002$

10) Gatalica $Z:$ Immunohistochemical analysis of apocrine breast lesions. Consistent over- expression of androgen receptor accompanied by the loss of estrogen and progesterone receptors in apocrine metaplasia and apocrine carcinoma in situ. Pathol Res Pract 193 : 753-758, 1997

11) Tavassoli FA, Purcell CA, Man $Y G$ : Down regulation of $b c 12, E R, P R$ associated with $A R$ expression is triggered by apocrine differentiation of mammary epithelium. Mod Pathol 9: 25A, 1996

\title{
A CASE OF WIDESPREAD APOCRINE DUCTAL CARCINOMA IN SITU OF THE BREAST
}

\author{
Hidenobu OKINO, Kazuo SHIMADA, Jiro WATANABE*, \\ Shoshu MITSUYAMA**, Takakazu SASAGURI*** and Shigeaki TAKEDA \\ Departments of Surgery \& Clinical Research and Pathology*, National Hospital Organization, Kokura Hospital \\ **Department of Surgery, Kitakyushu Municipal Medical Center \\ ***Department of Second Pathology, University of Occupational and Environmental Health
}

A case of widespread apocrine ductal carcinoma in situ (ADCIS) is herein reported. The patient was a 44-year-old woman who complained of a huge lump in her right breast. The findings of the mammography, ultrasonography and core needle biopsy were compatible with ductal carcinoma in situ (DCIS). The result of sentinel lymph node biopsy was negative, therefore, a simple mastectomy was performed. Histological examination revealed this tumor as ADCIS with immunohistochemically positive for gross cystic disease fluid protein-15 (GCDFP-15) and HER-2 and negative for estrogen receptor, progesterone receptor and androgen receptor. ADCIS has unique morphologic and hormonal profiles, distinct from common DCIS, which would deserve a specific classification. 